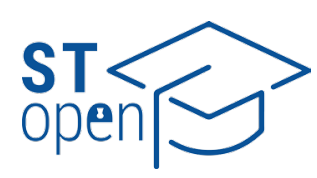

(c) 2020 The Author(s)

ST-OPEN @ 2020

\title{
Delimitation of co-perpetration from aiding and abetting in the criminal offence of robbery
}

\author{
Vedran Mijanić, Lucija \\ Sokanović
}

Faculty of Law, University of Split, Split, Croatia
Correspondence to:

Lucija Sokanović

Faculty of Law, University of Split,

Domovinskog rata 8, 21000 Split, Croatia

lucija.sokanovic@pravst.hr

\begin{abstract}
Aim: Analysis of the case law related to the prosecution of the criminal offense of robbery. Robbery is a complex criminal offense committed when a perpetrator uses force against another person, as well as when they threaten to directly endanger one's life or cause physical injury, or when they seize another's movable property with the aim of misappropriating it.
\end{abstract}

Methods: In selected cases, the application of main theories regarding complicity was examined and critically tested, taking into account the findings of the fact.

Results: The analysis of the current case law points to the absence of clear criteria for the delimitation of complicity from aiding and abetting in the criminal offense of robbery. Criminal law theory leaves too much empty space subject to manipulation when, by mentioning substantial contribution, it refers to behaviors without which an offense could not have been committed in the planned manner. The will of the perpetrator should constitute a secondary tool to be used only in controversial, borderline situations, where the nature of the behavior not pertaining to the essence of the criminal offense, due to its character and importance within the joint plan, requires it to be equated with the perpetration act. In that regard, as the joint plan is not a term that can be fully objectified since the importance of roles within the plan can vary from one group of perpetrators to another, assessing the will of the perpetrator can be an alternative to resort to in situations where it is not possible to evaluate the quality of a behavior based on objective rules.

Conclusion: Uneven case law in the evaluation of the behavior of individual participants in robbery contributes to the inequality of citizens before the law and endangers legal security - one of the foundations of the rule of law. 
tonomous (personal, direct), indirect or co-perpetrators. In addition to perpetration, the Criminal Code also distinguishes between two forms of complicity in the narrow sense - incitement and aiding and abetting (Kurtović Mišić \& Krstulović Dragičević, 2014). However, criminal law theory also recognizes the concept of complicity in the broad sense, which, in addition to the accomplice and the instigator, also includes the co-perpetrator (Kurtović Mišić \& Krstulović Dragičević, 2014). Although the difference between perpetration and complicity in a criminal offense is precisely determined both theoretically and normatively, there are still pronounced problems in their delimitation in practice (Garačić, 1999). This is especially true when it comes to the criminal offense of robbery, notably if we take as an example those robberies involving the participation of two people or a group of people with clearly divided roles and a perpetration plan (Lackner \& Kühl, 2007). Such a modus operandi often involves a person who drops off and picks up other members of the group, with one of them often standing guard at the entrance to the facility where the robbery is taking place, while the remaining participants misappropriate the property constituting the object of the criminal offense.

There are three aims of this article: (1) to show the inconsistency of the case law regarding the evaluation of the behavior of individual participants in the criminal offense of robbery, (2) to show the superficiality and the overuse of formulaic expressions in the explanations of the decisions of the Supreme Court, and (3) to show the shortcomings of the theory of control over the act.

\section{Methods}

The examined court decisions were divided into two basic categories. The first group consisted of those decisions where the court qualified the participant - the person who did not personally commited the act pertaining to the essence of the criminal offense - as an aider and abettor. One could conclude that such an attitude of the courts is slightly dominant, but it is not settled case-law. The second group consisted of those judgments when the person who did not commit the perpetration act was convicted as a co-perpetrator, as their contribution was considered significant. In the highest number of cases, the focus was on the persons who either had the role of a lookout during the robbery or who took direct perpetrators to the crime scene by car, to then remain waiting for their "colleagues" in the car in order to ensure their escape following the formal completion of the offense. The reason why we put special emphasis on such decisions lies in the fact that said two types of behavior constitute the most common patterns of behavior in the robbery, and they are also the most controversial in terms of qualifying them in practice. In order for one to be able to understand our research, we would like to point out that the judgments of the Supreme Court often contain summary explanations which frequently do not provide sufficient information. On the other hand, the decisions of lower courts, which contain complete findings of fact, in most cases are not available in electronic format. When it comes to the selected decisions, first there is a brief factual description of the offense, followed by an excerpt from the explanation of the Supreme Court and an analysis and critique of the elements at issue. 


\section{Aiders and abettors in robbery}

\section{Case 1: driver and checking if "the coast is clear"}

Three defendants have been convicted of robbery (one completed and one attempted), as well as of conspiracy to commit a criminal offense (i.e. robbery). The completed criminal offense of robbery was committed in the following way: the defendant DK had the role of the driver, while the defendant HF informed the third defendant DV that he could go ahead with the perpetration act after checking if "the coast was clear", after which the third defendant committed the offense. The Court of First Instance convicted all three defendants as co-perpetrators in the said robbery, but the Supreme Court overturned said decision following the defendants' appeals, convicting the defendant DK and the defendant HF as aiders and abettors in the robbery. As for the second offense - attempted robbery - the direct perpetrator was the defendant HF, while the defendant DB had the role of the lookout in front of the post office in question. The defendant HF was ultimately convicted of attempted robbery, while the defendant DB was convinced of aiding and abetting attempted robbery.

"In fact, the acts committed by the defendant HF and the defendant DK described under item 1 (when the defendant DK had the role of the driver of the car used as a means of transport to the scene of the robbery, and the defendant HF informed the defendant DV that he could go ahead with the robbery after checking if the coast was clear), as well as the acts committed by the defendant $D B$ described under item 2 (namely the fact that said defendant stayed in front of the post office, standing guard so no-one would witness the fact that the defendant HF was committing a robbery), in the opinion of the Court of Second Instance, are to be legally qualified as complicity in the criminal offense of robbery referred to in Art. 218, Para. 2 of the CC/97, namely by aiding and abetting, and thus in conjunction with Article 38 of the $C C / 97$.

Consequently, by legally qualifying the above acts committed by the defendants $D K$, $H F$ and DB as a criminal offense of robbery referred to in Art. 218, Para. 2 of the CC/97, the Court of First Instance violated the Criminal Code referred to in Art. 368/ 4/ of the CPA/97, as in the actions of said defendants there were elements of the criminal offense of aiding and abetting a robbery referred to in Art. 218, Para. 2, in conjunction with Art. 38 of the CC/97.

Therefore, under Art. 390 of the CPA/97, the appeals of the defendants DK and DB regarding said facts had to be upheld, and following said appeals within the meaning of Art. 383 of the CPA/97, a new qualification also had to be applied to the defendant HF who did not lodge an appeal. The first instance judgment had to be modified by changing the legal designation of the offense (i.e. the acts committed by said defendants), which the Court of First Instance qualified as a robbery referred to in Art. 218, Para. 2 of the CC/97, into the criminal offense of aiding and abetting a robbery referred to in Art. 218, Para. 2, in conjunction with Art. 38 Of the CC/97, as ruled under item 1 of the dictum of this second instance judgment" (Supreme Court of Croatia, September 1, 2015). 
Case analysis

There is no doubt that the commission of the offense was preceded by an elaborated plan involving the division of roles, according to which DK was to drive the perpetrators to the scene of the crime, while HF was to make sure that the "coast was clear" and ultimately inform DV (the direct perpetrator) thereof. That way, based on the division of roles, each participant achieved functional control over the act. That was especially true in the case of the defendant HF, as without him informing DV that he could go ahead with the offense, the offense would not have been committed at all. It is therefore common ground that the duo in question contributed significantly to the commission of the offense. What does "functional control over the act" mean? The term "functional control over the act" is used by Roxin, a famous German law professor and the most famous representative and advocate of the theory of control over the act (Novoselec, 2011). It is a dominant theory that our legal system took from the German legal system, and it is also reflected in the definition of co-perpetration referred to in Art. 36, Para. 2 of the Criminal Code. It states that if several persons commit a criminal offense based on a joint decision in such a way that each of them participates in the commission of the offense or significantly contributes to the commission of the offense in some other way, each of them shall be punished as a perpetrator. For Roxin, functional control is the guiding idea for determining co-perpetration, and combined with a joint plan, it forms the backbone of its interpretation. He points out that the co-perpetrators' contribution to the offense at the stage of its commission shall constitute a functionally significant part of the joint commission of the offense on the basis of a joint decision, as well as that whenever the planned contribution is eliminated, so is the offense itself in the form provided by the joint plan and division of roles (Bojanić, 2002).

As for prominent names from Croatian criminal law theory, the closest one to Roxin's conception of the theory of control over the act is Novoselec. He also uses the term "functional control over the act" and brings it to life with an example from case law, namely a decision of the Supreme Court where three members of a group were convicted as co-perpetrators in the criminal offense of robbery, which was committed in such a way that one member of the group drove the other two members to the store they robbed, forced the saleswoman to hand them over all the money at gunpoint, and the third one took the merchandise from the store. After that, they all fled in the car where the first member of the group was waiting for them, and they split the take (Supreme Court of Croatia, March 10,1993). In this case, the Supreme Court dismissed the appeal of the defendant whose role was to drive the other two co-perpetrators to the store and ensure their escape. Noveselec approves of said decision, namely with the following arguments: "The perpetrators jointly committed the criminal offense in question, based on the division of roles, with each of them having a function significant for the realization of their plan, and thus also functional control over the act. By controlling their function, a co-perpetrator also controls the act as a whole; if any of the co-perpetrators had failed to perform the task entrusted to them, the joint plan would have failed. However, this does not mean that in order for co-perpetration to be present, it is necessary that the offense could not have been committed at all without the individual contribution in question, but only that it could not have been committed in the manner in which it had previously been planned " (Novoselec \& Bojanić, 2013). However, it is possible for equivalent behaviors (keeping guard or driving the perpetrator to the 
scene of the crime and ensuring their escape after the formal completion of the offense) to be considered aiding and abetting in one case, and perpetration in another. "As a rule, keeping guard constitutes a significant contribution to the commission of an offense and is therefore a form of co-perpetration, but according to our courts, it can also be just aiding and abetting whenever the lookout has an insignificant role, leading to the conclusion that the crime could have been committed in the manner in which it had previously been planned even without said contribution” (Novoselec \& Bojanić, 2013). Novoselec rightly demands that the significance, quality and weight of a contribution should be examined in each individual case. Similarly, Roxin believes that, as a rule, a lookout should be qualified as a co-perpetrator. However, he makes room for the possibility that they be qualified as an accomplice. For instance when an experienced gang of robbers starts training a new member by giving them the role of their lookout, which for them as experienced robbers is not of crucial significance in terms of committing the offense as jointly planned (Bojanić, 2002). Thus, Roxin, just like Novoselec, leaves the delimitation of co-perpetration from aiding and abetting in challenging situations in a pending state in theory, leaving it up to the judge to make a decision taking into account all circumstances of the case.

Accordingly, discussions regarding whether or not the defendant DV could have committed the offense without the driver, or even without the person whose role was to inform him that it was safe to go ahead with the offense, are not relevant, as even if that were the case, the definition of co-perpetration does not require that the offense could not have been committed at all without the participants in question, but that it could not have been committed in the manner in which it had previously been conceived and planned. The explanation of the judgment in question also shows that the defendants were required to pay the following amounts on account of material gain pertaining to the criminal offense in question; HF and DK HRK 847.25 each, and DVV. HRK 3,275.00. That shows that the goal of each defendant was to obtain material gain through criminal activities. Regardless of the abandonment of subjective theories, determining the perpetrator's will could clarify the situation in such borderline cases, provided that the will is viewed in the context of the goal that the offense is intended to achieve, as every completed criminal offense leads to a consequence realized by its commission. In case of doubt as to whether a person who does not commit the act pertaining to the essence of the criminal offense should be classified as a perpetrator, i.e. whether their acts should be qualitatively equated with those of the direct perpetrator, the best criterion is to assess whether the person in question, although they did not commit the perpetration act itself in the occasion in question, still wished to achieve the goal of that criminal offense? If the criminal offense of robbery is committed by a direct perpetrator and a lookout who on that occasion stole HRK 10,000, which they divide in such a way that the direct perpetrator gets HRK 6,000 as their role is more difficult, and the lookout gets HRK 4,000, it would be illogical and unrealistic to qualify such a lookout as an aider and abettor. Since their goal was to obtain material gain from the offense, the fact that, based on a joint plan, the duo concluded that in said situation they would have a better chance of successfully committing the offense if one person used force or threat to steal the money, and the other kept watch instead of them both committing the perpetration act, does not at all constitute the reason to question whether the lookout was a co-perpetrator or an aider and abettor. The foregoing is supported by the fact that the 
lookout, regardless of the fact that they did not commit the act pertaining to the essence of the criminal offense, indeed had control over the act within the joint plan, as they could actively influence the perpetrator, warn them of the danger of being discovered, or ruin the offense with their negligence. In addition to the above, it is common ground that in said case one cannot say that the defendants HF and DK perceived the offense as someone else's, i.e. that they only wanted to help the defendant DV in his offense. It is also common ground that, within the joint plan, they had functional control over the act. All of the above also applies to the defendant DB, who in the second case had the role of a lookout. Furthermore, the other two criminal offenses shall also be taken into account. We are not alluding to any unfair extension of liability, primarily that of the defendant HF for his participation both in said attempted robbery and in the plan to commit the criminal offense, but to the fact that the participation in two more crimes undoubtedly shows that said group is a group whose goal was to obtain material gain through criminal activities. Thus, it is unjustified to qualify some of them as aiders and abettors only because of their internal division of roles, all the more so whenever each of said roles is of equal importance within their joint plan, which was clearly the case (Donatsch, Flachsmann \& Hug, 2010).

\section{Case 2: informing the driver of the direct perpetrator's exit from the facility}

The defendants AM, ZP and MD were found guilty by the Court of First Instance of two counts of robbery, three counts of aggravated theft, and one count of attempted aggravated theft. In both criminal offenses of robbery, both the one related to a bakery and the one related to a gas stations, the defendant AM was convicted as a co-perpetrator in robbery together with the defendants ZP and MD. Their modus operandi involved the defendant ZP driving the car in which the defendants came to and left the scene of the crime, with the defendant MD always being the direct perpetrator. The defendant AM appealed the decision regarding the sentence, and the Supreme Court overturned the judgment of the Court of First Instance ex officio, considering that both in the case of said robbery related to a bakery and in the case of the robbery of said gas station, the defendant AM had no control over the act, which is why her actions were those of an aider and abettor in a robbery. In her testimony, the defendant AM stated that defendant ZP obtained the means for the commission of said crime and handed them over to the defendant MD, who stole money from the bakery while holding the salesperson at gunpoint. The role of the defendant AM in the offense in question was to report MD's exit from the bakery in a timely manner, after which ZP started the car so they could escape.

"However, in items 1 and 2 of the dictum of the judgment, the Court of First Instance erroneously assessed the acts of the defendant AM as acts committed by a co-perpetrator. Given the fact that, according to item 1, the defendant AM remained outside, waiting for the return of the defendant $M D$ (who entered the bakery with a gun in order to steal money), and that her role was to inform the defendant ZP to start the getaway car in a timely manner, as well as that during the event referred to in item 2 of the dictum of the judgment, the defendant AM was waiting in the getaway car for the defendant $Z P$ and the defendant $M D$ to rob said gas station at gunpoint, the described actions of the defendant AM show that she had no control over the act as the outcome of the offense did not depend on her, but she only had the role of 
an aider and abettor. Therefore, in that part, the judgment under appeal violated the criminal code at her expense, and it thus should have been decided ex officio as under item 1 a) of this decision” (Supreme Court of Croatia, February 18, 2010).

\section{Case analysis}

The Court of First Instance correctly qualified the defendant AM as a co-perpetrator in the criminal offense of robbery. The Supreme Court justified its qualification by stating that the defendant AM had no control over the act, i.e. that the outcome of the offense did not depend on her. The chamber did not provide an answer to the question of why that is so, i.e. what the court based such a conclusion on. Such controversial and borderline situations require meticulous and reasoned explanations. The definition of the theory of control over the act is based on the breaking down of the legal description of co-perpetration into two components, the objective one and the subjective one. The objective component refers to the existence of a "significant, substantial, noticeable" (German: erheblich) contribution in the stage of commission of a criminal offense, while the subjective one refers to the existence of a joint decision (Pavlović, 2015). Consequently, stating that someone is not a co-perpetrator because they have no control over the act constitutes a circular explanation. Such a claim is equivalent, for instance, to the one stating that someone is not guilty because they did not act with intent, without stating a single fact that would support such a thesis. Going back to the role of the defendant AM, it is clear that it involved her waiting outside for the return of the direct perpetrator (the defendant MD) and then informing the third member of the group (the defendant ZP) to start the getaway car, meaning that her role is twofold. In fact, by waiting outside for the return of the defendant MD, she had the role of a lookout, and upon his return, she performed the role of a mediator, namely by informing the third member of the group that they were ready to escape. Thus, the defendant AM had a direct influence on both co-perpetrators, and she indeed had control over the act, as by not performing her role, she could have ruined the offense, i.e. prevented its commission in the planned manner, meaning that she in fact had an important role in the plan even though she did not commit the perpetration act itself. Furthermore, by noting that "the defendant AM had no control over the act as the outcome of the offense did not depend on her", the Supreme Court assessed the quality of her contribution ex post, which was not the right thing to do. The fact that the offense was completed without the need to "directly engage" the defendant AM in it does not diminish the importance of her contribution within the joint plan. Had the defendant AM noticed a police officer approaching the crime scene while waiting for the direct perpetrator MD and subsequently informed the other co-perpetrators thereof, thus warning them of the impending danger, the court would have certainly agreed with the claim that the defendant AM had control over the act, especially since such a modus operandi was the result of a joint plan, which the defendant AM herself admitted in her testimony. The fact that she remained passive in the case in question does not diminish the importance of her role within the joint plan. Looking at the role of the defendant AM ex post, one could indeed conclude that her contribution was not significant, as the direct perpetrator committed the offense without her direct engagement, i.e. the need for her to react or warn him of a possible danger. The problem with such a perception is reflected in the fact that following that logic, any lookout who did not 
have the need to react as there was no objective danger to them or to the members of their group would be just an aider and abettor. On the other hand, any lookout who warned a member of the group or the direct perpetrator of a danger for the completion of the offense at least at one point in time would be a co-perpetrator. The reason for said illogical conclusion of the court, stating that the defendant AM did not significantly contribute to the commission of the offense as its outcome did not depend on her, although it is clear that without her role the commission of the offense would have been more difficult and risky, lies in the fact that the situation was observed after the commission of the criminal offense. Consequently, it is obvious that such a position is both realistically and legally illogical and inadmissible, which is why it is always necessary to approach a case ex ante, i.e. assess the role of such a participant within the joint plan. The judgment does not provide information on the amount of money stolen, nor does it provide information on the distribution of the take. However, just like in the previous case, the number of criminal offenses committed by the group of defendants indisputably indicates that they aimed to unlawfully acquire material gain. Furthermore, a uniform modus operandi in all of the offenses committed is an indication of a joint plan based on a strict division of roles. All of the said indicators point to a joint commission of offense, that is, to co-perpetration (Krey, 2008).

In addition to the fact that the Supreme Court overturned the judgment of the Court of First Instance in item 1 (robbery of a bakery) ex officio, qualifying the defendant AM as an aider and abettor in the robbery, it remains unclear why it did not qualify the defendant ZP (the driver of the getaway car) as an aider and abettor on the basis of the same criterion since the degree of his criminal involvement is at least equal to, if not objectively lower than that of the defendant AM. Thus, if according to the chamber, the defendant AM had no control over the act as the outcome of the offense did not depend on her, then surely the defendant ZP had no such control either, as he did not have a direct influence on the direct perpetrator in any way up to the point when the act was formally completed.

\section{Case 3: provision of disguise for the commission of the offense and the getaway driver}

The defendant DS drove the defendant MK to a pharmacy. The defendant DS gave the defendant MK glasses and a hat so that he could disguise himself. The defendant MK committed the criminal offense of robbery at the pharmacy, to then return to the car driven by the defendant DS, who drove them both away, thus ensuring their escape from the scene of the crime. The Court of First Instance found the defendant DS guilty of aiding and abetting a robbery, while the defendant MK was found guilty of committing the criminal offense of robbery. In addition to the accused, an appeal was also lodged by the State Attorney, namely due to a violation of the criminal code and the decision regarding the sentence, proposing that the judgment under appeal be reversed when it comes to the legal designation of the offense committed by the defendant DS, namely by finding them guilty of co-perpetration instead of aiding and abetting a robbery, as well as that both defendants be sentenced more severely. The Supreme Court dismissed the appeal of the State Attorney as unfounded in part related to the violation of the criminal code, upholding the judgment 
of the Court of First Instance, where the defendant DS was convicted as an aider and abettor in a robbery.

"However, the Court of First Instance was right not to accept said thesis of the State Attorney, as from the presented evidence it does not follow that the defendant DS participated in the commission of the criminal offense in question as a co-perpetrator within the meaning of Art. 35 Para 3 of the CC. The Court of First Instance is right to point out that it does not follow from the factual findings that the defendant $S$ significantly contributed to the commission of the robbery with his actions, as he in fact only facilitated its commission.

The Court of First Instance was right to conclude that the defendant S, by driving the defendant $K$ to the pharmacy, waiting for him to steal the money and then driving him away from the scene of the crime, had contributed to the commission of the crime, but not significantly.

In other words, it is evident that the criminal offense in question could have been committed even without the acts of the defendant $S$, but that would have been more difficult for the defendant $K$, and the risk of him getting caught would have been higher. Thus, the defendant $K$ only aided the perpetrator, but his actions did not significantly contribute to the commission of the criminal offense. Concerning the subjective component of co-perpetration, the Court of First Instance was right to point out that the finding that there was a prior agreement between the defendants is not an argument for stating that the defendant $S$ also had control over the act.

The Court of First Instance was also right to point out that the set of circumstantial evidence/clues indicates that there was a prior agreement between the defendants, but that the role of the defendant $S$. was to aid the defendant $K$ in the commission of said robbery, meaning that it was not his will to participate in the commission of said offense, but to aid the perpetrator. The existence of an agreement, therefore, does not necessarily imply co-perpetration, since an accomplice, and not only a co-perpetrator, can also have a prior agreement with the perpetrator as to what their role in the planned event will be" (Supreme Court of Croatia, April 9, 2008).

\section{Case analysis}

It is clear from the explanation of the judgment that the Supreme Court, just like the Court of First Instance, considers the contribution of the defendant DS to be insufficiently significant to speak of co-perpetration. The problem is that such a position stems from an explanation which is contradictory to it, as whenever the court believes that without the actions of the defendant $S$ the commission of the criminal offense would have been more challenging, i.e. that there would have been a greater possibility for the direct perpetrator to get caught, how can such a contribution not be assessed as significant? Novoselec also disapproves of such inconsistencies. According to him, only the contribution without which an offense could have been committed with an almost equal risk as with it, is to be assessed as insignificant (Novoselec, 2010). 
Furthermore, in its explanation, the Supreme Court also points out that the will of the defendant DS was to aid another in their offense, and not be the perpetrator in his own offense. Thus, it in fact defends the qualification of aiding and abetting with the dolus theory. However, according to Novoselec, the combination of subjective theory and the theory of control over the act only creates additional confusion, making it even more difficult to distinguish between co-perpetration and aiding and abetting (Novoselec, 2010). Subjective theories are based on a broad interpretation, and they consider anyone whose actions affect the commission of a criminal offense in any way to be the perpetrator (Horvatić, Derenčinović \& Cvitanović, 2017). In this example, we can see that subjective theories are still present in the explanations of judgments, especially when it comes to the dolus or the interest theory, given that both those theories base the idea of delimitation of co-perpetration from aiding and abetting on a psychological element, i.e. the so-called will of the accomplice (German: Teilnehemerwillen), which pertains to the participant who perceives the offense as someone else's (cum animo socii), as opposed to the perpetrator who acts based on their autonomous will of the perpetrator (German: Täterwillen), while at the same time having full control over the decision regarding the consequences, and perceiving the offense as their own (cum animo auctoris) (Roxin, 2003). The aforementioned will of the accomplice is the term used by the chamber of the Supreme Court in qualifying the defendant DS as an aider and abettor, emphasizing that his will was to aid the defendant DS, which leads to the conclusion that he did not perceive the offense as his own, but as someone else's.

First of all, it should be noted that in the part of the explanation where it refers to the will of the accomplice, the Supreme Court does not give any explanation on which it bases its conclusion - that the goal of the defendant DS was only to aid the second defendant in the commission of his offense. Unlike Novoselec, who disapproves of the combination of the dolus theory and the theory of control over the act, we believe that subjective theory, if used correctly, can serve as an additional tool in such borderline situations. Thus, the following question should be asked: what is the criterion on which the court distinguishes between the will of the co-perpetrator and that of the accomplice? The criterion should be the gain obtained by the act, that is, the spoils as the reason for robbery. Will is a psychological component which shows the attitude of the perpetrator towards the criminal offense. In that regard, the spoils, or their division, is the best indicator of whether someone perceives the act as someone else's, or if they wish to benefit from the spoils as much as possible, and thus fulfill the goal of the criminal offense of robbery. If someone benefits from the offense to a substantial extent, then we cannot say that such a person perceives the offense as someone else's. In addition, the division of the spoils in a way that does not put a significant emphasis on the direct perpetrator points to both equality among the participants and the importance of the acts of the person who does not commit the perpetration act itself, as well as to a clear existence of a plan. In addition, we are not referring to any code of honor among criminals, nor do we consider the reasons for the distribution to be the primary criterion to take into account when qualifying them. Nevertheless, the division of the spoils in said way undoubtedly points to the existence of the will of the perpetrator, which is manifested in the desire to achieve the goal of robbery. It is interesting that the unreliability of assessing the will, i.e. the psychological component, is pointed 
out as the reason why subjective theories should be avoided. In that regard, we believe that the assessment of the quality of contribution within the joint plan poses the same problem. The joint plan should constitute a framework within which the quality of each participant's contributions is assessed. However, the plan as such cannot be fully objectified (Fabrizy \& Foregger, 2010). If we were to completely rationalize everything, only the accused indeed know how important each individual role is for the realization of the plan. Therefore, the court does not have clear guidelines to follow when adopting a decision. It should be noted that in their appeal, the State Attorney pointed out that the goal of both defendants was to obtain a material gain, and thus both the subjective and objective component of co-perpetration were achieved in the actions of the defendant $\mathrm{S}$. That does not mean that the element of spoils should become the central criterion for the delimitation of perpetration from complicity. However, it should certainly not be marginalized, given the fact that stealing the spoils constitutes the primary goal of any robbery.

\section{Case 4: informing the perpetrators when the time is right to commit the offense}

The criminal offense of robbery constituting the object of the above judgment was committed in such a way that the defendant NV was the first one to enter the slot machine club which was the target of the robbery, only to spend some time waiting for an opportune moment for the commission of the offense. When she was convinced that the time was right, she informed the defendants NM and PR that they could go ahead with the perpetration act. As soon as the defendants NM and PR arrived, the defendant NV left the slot machine club and said two defendants subsequently committed the robbery. The Court of First Instance found the defendant NV guilty of aiding and abetting said criminal offense of robbery. The defendant NV appealed through her defense attorney against erroneously established findings of fact, proposing that the judgment under appeal be overturned and that the accused NV be acquitted, i.e. that the judgment under appeal be set aside, and the case be referred back to the Court of First Instance. The Supreme Court concluded that the Court of First Instance did not make a mistake by qualifying the actions of the defendant $\mathrm{NV}$ as those of an accomplice.

"The actions of the defendant $N V$ were aimed at informing and providing the perpetrators with a convenient moment when they could safely enter the slot machine club, thus creating favorable conditions for the commission of the criminal offense in question.

The actions of an accomplice mean a contribution to the realization of the offense, and they must also have a certain effect on the commission of the offense. Aiding and abetting requires effective support for the principal offense, as well as the creation of favorable conditions for the perpetrators. Aiding and abetting means any assistance that objectively supports and betters the commission of the act itself. As the accomplice removes the perpetrators' worry as to whether or not they can commit the offense, meaning that they consequently feel safer during the commission of the offense, it is quite clear that with her actions, the defendant NV satisfied all essential features of the criminal offense of aiding and abetting a robbery. She acted according to a preconceived plan, intending to help others in stealing other people's 
movables with the aim of misappropriation, namely under the threat of directly endangering one's life or causing one physical injury" (Supreme Court of Croatia, October 21, 2008).

Case analysis

The Supreme Court upheld the qualification of the Court of First Instance, and it defended such a position claiming that the defendant NV created favorable conditions for the commission of the offense. From that, it could be concluded that, according to the court, the defendant did not significantly contribute to the commission of the offense, but that her behavior remained within the limits of aiding and abetting. The actions of the defendant NV can be classified as preparatory actions. In assessing whether the actions of the defendant NV pertain to co-perpetration or aiding and abetting, it should first be clarified whether preparatory actions can take on a co-perpetration nature at all. According to Roxin, a significant contribution at the stage of the commission of the criminal offense is required, and since the defendant NV did not act in tempore criminis, the objective component of the theory of control over the act was not realized according to Roxin's conception. Zlatarić, the founder of the theory of labor division, also states that a significant contribution in the stage of commission of the offense is required. The fact that both of them base co-perpetration on a significant contribution in the commission stage is, in fact, what we consider to be the greatest shortcoming of the above theories. Regardless of the fact that a contribution in a certain situation is appreciated as significant, and perhaps even crucial for the commission of the offense, it will not be considered co-perpetration if it does not fall within the time frame of the commission stage. Therefore, in order for co-perpetration to materialize, according to Roxin, the contribution must be significant, and it must also occur after the direct perpetrator at least entered the attempt stage. The application of such a rule leads to unjustified exculpations of participants whose actions are possibly crucial to the success of the criminal offense, namely only because they did not act at the time of commission.

According to Roxin's conception of the theory of control over the act, for instance, a person with extensive knowledge in the field of computing who, as a member of a group of robbers, switches off a bank's security system before the direct perpetrators enter the facility and commit robbery, could not be qualified as a co-perpetrator since, although such contribution is crucial, it does not coincide in time with the act of commission. However, if a joint plan is the focal point of Roxin's conception, then significant contributions should be assessed from the aspect of said joint plan, not only in terms of content, but also in terms of time and space. Accordingly, the fact that a person has full control over the fate of the whole offense is much more important than the fact that they do not meet the condition of acting in tempore criminis. Thus, if a joint plan is taken as the central element, which is the right thing to do, then said the joint plan should constitute both the temporal and the spatial framework within which the contribution in question should be assessed. If a certain preparatory action is a constituent element of a joint plan, i.e. if it marks the beginning of the plan, and if the importance of that action is indisputable, which is reflected in the fact that without it the offense could not have been completed in the planned manner, then it is illogical and generally unrealistic to deprive such a preparatory action of its co-perpe- 
tration nature only because it does not fall within the time framework of the commission of the offense. This is especially evident in situations where without a specific preparatory action there would be no offense at all, or where its commission would involve much higher risk. In that regard, not every preparatory action has equal value, nor is it equally important for the success of the offense, which is why it is necessary to make a distinction between such actions. For instance, providing one with the means for the commission of the offense constitutes a preparatory action, and it is also a textbook example of an action of an accomplice. There are no doubts whenever the means is a gun or a knife, but what if it is an instrument used to open safes, that is, some kind of a special key without which the commission of the offense would not be possible at all, or it would at least involve much greater risk and more difficulties? Considering of all the above, we believe that the requirement that the contribution be simultaneous with the perpetration act is unnecessary, as it unjustifiably exculpates the participants whose actions are possibly crucial for the commission of the offense in the planned manner. In addition, the fact that someone does not act at the time of the commission of the offense does not mean that, as part of their role, they did have control over the fate of the offense, i.e. the criminal process. On the contrary, it is possible that this very action constitutes the first link in the chain and is a requirement for the act pertaining to the essence of the offense to be possible at all. Precisely for that reason, the subject of the court's assessment should be the following question: did a preparatory action really only create favorable conditions for the commission of the act, or was said preparatory action essential in such a way that without it the offense could not have been committed in the planned manner without greater difficulties and risks? The answer to that question will also be the answer to the question whether in those cases one is taking about aiding and abetting or co-perpetration. In his recent works, Novoselec moves away from Zlatarić and Roxin when it comes to preparatory actions, citing examples from case law that support his understanding that a preparatory action can constitute co-perpetration if the contribution is significant; for instance, in case a participant visits a store only to inform other two participants of the situation inside, with them subsequently committing a robbery at the store (Novoselec, 2016).

If we compare the aforementioned example with the criminal offense under analysis, a clear parallel can be drawn, as the role of the defendant NV also involves scouting, and especially since she does it immediately before the commission of the offense. When upholding the qualification of the Court of First Instance, an explanation based on the "creation of favorable conditions" is certainly not sufficient. In fact, any contribution to the commission, whether significant or insignificant, could be characterized as the creation of favorable conditions. The driver who drops off the perpetrator, the lookout guarding the entrance to the facility, and the participant who gives the perpetrator the means for the commission of the offense also create favorable conditions for the commission. The real question is to what extent the creation of such conditions significantly contributes to the commission within the joint plan. In the case in question, the defendant NV has the task to inform the co-perpetrators when the time is right for the commission of the offense. The fact is that said defendant was at first the only one present at the slot machine club which was the target of the robbery, as well as that without her role, which was undoubtedly a product of a joint plan, the offense might not have been committed in the manner in which 
it had been planned. Let's not forget, the definition of robbery does not require that the offense could not have been committed at all, but that it could not have been committed in the planned manner. If we also add the fact that the case law recognizes the qualification of scouting as a co-perpetration act, it is clear that the court would not have made a mistake if the defendant NV had been qualified as a co-perpetrator.

\section{Co-perpetrators in robbery}

\section{Case 1: keeping guard}

Four defendants committed a robbery at a post office. Based on a joint plan, they divided their roles in such a way that the defendant IK drove the defendants IŠ and BA to the post office. While the latter two were stealing money at the post office at gunpoint, the defendant IK was waiting for them to exit with his car engine running. The defendant TČ, in charge of keeping guard, was also sitting in his car parked across from the post office. The Court of First Instance convicted all four as co-perpetrators in a robbery, and the Supreme Court upheld such a qualification when deciding on the defendants' appeals.

"According to the description of the defendants' actions contained in the dictum of the judgment under appeal, "according to the previously elaborated plan and agreement" between all the defendants, the defendant IK "used his personal vehicle (...) to drive the first defendant IŠ and the second defendant $B A$ to the post office $H-H$, and with the car engine running, waited for them to exit while sitting in his car parked behind the post office", while the defendant TČ, also in accordance with said plan and agreement, "was sitting in his parked car across from the post office in order to be able to warn the first defendant IŠ and the second defendant BA whenever a person came by" while the defendants $\breve{S}$ and A were stealing money from the post office $H$ at gunpoint.

The acts of the defendant $K$, which involved driving the defendants $\breve{S}$ and $A$ to the scene of the crime (the post office) so that they could commit said robbery, and then waiting for them to complete the offense and driving them away from the scene of the crime, as well as the acts of the defendant $\check{C}$, which involved "keeping guard" or observing the scene of the crime in order to timely warn the defendants $\check{S}$ and $A$ of the arrival of any persons who could jeopardize the commission of the criminal offense, and in view of the aforementioned elaboration of the role of each defendant in the realization of the joint plan, as well as of the fact that the commission of the planned robbery directly depended on the defendants $K$ and $\check{C}$ who, by not taking the agreed actions (driving in case of the defendant $K$ ) or by their actions (notifying the defendants of someone's arrival) could have prevented or interrupted the offense, according to the Supreme Court of Croatia as a court of second instance, constitute co-perpetration acts within the meaning of Article 35, Paragraph 3 of the CC, as those are actions with which said defendants significantly contributed to the commission of the offense. The fact that all defendants were aware of said significance of the contribution of the defendants $\check{C}$ and $K$ to the commission of the 
criminal offense of robbery is also evident from their equal participation in the distribution of the money obtained during said criminal offense" (Supreme Court of Croatia, October 3, 2012).

\section{Case analysis}

Following the defendants' appeals due to a violation of the criminal code, the Supreme Court upheld the first instance judgment, establishing that both the objective and the subjective component of the theory of control over the act had been achieved. The Court first mentions the "previously elaborated plan and agreement" establishing the roles of the defendants IK and TČ, which involved dropping the perpetrators off / driving them away and keeping guard, respectively. After that, it points out that said contribution was significant since the defendants, as is evident from the quoted part of the explanation, were able to "prevent or interrupt" the commission of the criminal offense. It is particularly important to emphasize the Supreme Court's assessment regarding "the spoils". Said equal distribution of misappropriated money points to the (equal) significance of the contributions of the defendants IK and TČ, and it also confirms their will of the perpetrator. Thus, not only were the other defendants aware of the significance of the contribution of the defendants IK and TČ but said defendants also confirmed their will of the perpetrator themselves. Although the assessment of will is not the focus of the theory of control over the act, equal distribution of unlawfully acquired material gain should right away annul the idea that such participants aid another in the commission of their offense, which constitutes the starting point in case of aiding and abetting. The explanation of the Supreme Court is accurate, clear and meticulous.

\section{Case 2: driving the perpetrators to the scene of the crime, providing them with disguise clothing and a weapon, driving them away and dividing the spoils}

The defendants SG and BM committed a robbery of a pharmacy in such a way that the defendant SG drove the defendant BM to the scene of the crime, gave him disguise clothes and a knife, after which the defendant BM entered the pharmacy and stole the money at knifepoint. The defendant BM then returned to the car, where the defendant SG was waiting for him. The defendant SG drove the defendant BM to an unknown place where they split the stolen money. The Court of First Instance convicted them as co-perpetrators in the robbery, and the Supreme Court upheld said decision when deciding on the defendants' appeals.

"In his appeal lodged through his defense attorney, the defendant SG insists that he did not know that the defendant $M$ would commit a robbery, although he does not deny that he used his personal vehicle to drive him to said pharmacy in $S$, as well as that he gave the defendant BM his pants, T-shirt, hat and knife and stayed in the vehicle waiting for him, while BM entered the pharmacy, namely masked and with his face covered, threatened the saleswoman LĆ with a knife and stole HRK 1,600.00, to then return to the vehicle where the defendant $S G$ was waiting for him, after which they drove away and then divided the money. 
The Court of First Instance was right to conclude that the defendants acted jointly and in agreement as the defendant BM consistently stated in his defense from the investigation up to the main hearing, since even in the opinion of the Court of Second Instance, it is completely illogical that the appellant would take $M$ to the pharmacy, give him disguise clothes and a knife used to threaten the saleswoman so she would give him money, wait for him and split the money without knowing what $M$ intended to do.

Precisely for that reason, the complaint of the defendant SG stating that he was an aider and abettor cannot be accepted. The contribution and role of the appellant in the commission of the criminal offense goes beyond the elements of aiding and abetting, and it undoubtedly thus follows that he was in fact a co-perpetrator in accordance with Art. 35, Para. 3 of the CC.

Therefore, in the case of said defendant, the Court of First Instance correctly applied the criminal code by finding him guilty of the criminal offense referred to in Art. 218, Para. 2 of the CC" (Supreme Court of Croatia, January 8, 2008).

\section{Case analysis}

In this case, the Supreme Court also dismissed the defendant's appeal and rightly upheld the decision of the Court of First Instance. However, the court's arguments are scarce and reduced to the finding that the appellant's contribution and role in the commission of the offense went beyond the elements of aiding and abetting. The decisions of the Supreme Court are binding upon lower courts by virtue of their authority, which is why lower courts are not required to apply any legal position set out in a decision of a higher court. That is precisely why the explanations must be precise, detailed and substantiated, especially in borderline cases. At no time does the Supreme Court mention the control over the act, which is necessary in order to confirm the qualification of co-perpetration. The defendant SG does have control over the act, which stems from a joint plan and is manifested in him driving the direct perpetrator, giving his disguise clothes and a weapon, waiting for him and driving him away following the formal completion of the offense.

\section{Discussion}

The analysis of the current case law points to the absence of clear criteria for the delimitation of complicity from aiding and abetting in the criminal offense of robbery. Criminal law theory leaves too much empty space subject to manipulation when, by mentioning substantial contribution, it refers to behaviors without which an offense could not have been committed in the planned manner. The idea of such a conception is correct and just, but if we completely rationalize it, we can conclude that in the absence of contributions agreed on the basis of a joint plan, it would not be possible to commit an offense in the planned manner, otherwise the offense would have been planned without such contributions. Following that logic, any contribution could be assessed as significant, which is wrong. To clarify the criteria and narrow down the framework of delimitation of complicity from aiding and abetting by offering new solutions a further problem arises by 
providing alternative methods based on which the court applies the option that best suits a given case in order to justify the qualification it chose. Thus, different terms which are not synonyms and between which there are gradual differences are created, so when examining the case law, one can notice that some judges require there be considerable facilitating in order for co-perpetration to exist, while others require one's enabling that the act be committed without any major risks, and some require the fact that the offense could not have been completed in the planned manner without the contribution in question. However, the terms "considerable facilitating" and "without any major risks" can be extremely flexible when they are interpreted legally. As a consequence of such terminological differences, a system where the possibility of errors increases is created (and as we have seen, errors are indeed present). What certainly contributes to this is the specificity of the criminal offense of robbery, for which it is almost impossible to expect, whenever a group commits it, that each participant will commit the perpetration act and thus "make the judge's job easier". Does this mean that the contribution of a person who does not commit the act pertaining to the essence of the criminal offense is not significant enough, or is such a contribution always significant as it is the fruit of a joint plan without which it would not be possible to complete the crime in the planned manner? It is the infamous modus operandi involving a driver or a lookout, or in most cases both, that points to the fact that this is the easiest and probably the safest way for perpetrators to commit the offense in question. It may sound cynical, but if a lookout or a driver were not significant for the commission of the offense, then the direct perpetrator would not involve them in the offense at all. All of the above points add to the impossibility of fully objectifying the problem of delimitation of complicity from aiding and abetting. It is not possible to adopt an exact mathematical formula under which all drivers or all lookouts can be subsumed, or subsequently put into one category and qualified (either as aiders and abettors or as co-perpetrators). Said impossibility to bring equivalent patterns of behavior in different criminal offenses under a single rule and to qualify them as being the same is in fact the best indicator that other methods should be applied.

The infamous will of the perpetrator is no more difficult to prove than the (in)significance of a contribution, which must also always be assessed on a case-by-case basis, without any established criteria or rules based on which it can be placed within the framework of co-perpetration or aiding and abetting. That is why we should strive to prove the will of the perpetrator, give it more importance, and view it as an integral part of the subjective component of co-perpetration, especially since a joint plan alone is never enough, as it cannot constitute a differentia specifica between a co-perpetrator and an aider and abettor, since the latter can also make a plan with the direct perpetrator. The determination or grading of the will of the perpetrator will be facilitated if the importance of the spoils as the primary goal of the criminal offense of robbery (which is unjustifiably marginalized) is taken into account. With regard to the qualification of behaviors, there should be no difference between a person who unlawfully obtains material gain by keeping watch for the direct perpetrator based on their prior agreement and "the one holding the bag where the latter puts the money”. In both situations, the perpetrator's goal is the same, namely to unlawfully obtain material gain. Co-perpetrators are the ones who choose the manner of commission of the offense, namely guided by the criterion of having higher success, i.e. 
lower risk of being caught. It is also extremely important to point out that the problem of delimitation must not be compensated by sentencing. On the contrary, in the situations from the example, the punishment should serve as a means of distinguishing between the perpetrator with a greater criminal involvement and a greater degree of danger they create for the environment and the one who is harmless to others in their role. As far as their qualification is concerned, they both act with the same will, volition and motive and are aware of the importance of their roles for the purpose of realizing the plan and completing the offense in the planned manner. When using the argument of the will of the perpetrator, the important thing is that it must not be given priority over objective criteria. Said will should constitute a secondary tool to be used only in controversial, borderline situations, where the nature of the behavior not pertaining to the essence of the criminal offense, due to its character and importance within the joint plan, requires it to be equated with the perpetration act. In that regard, as the joint plan is not a term that can be fully objectified since the importance of roles within the plan can vary from one group of perpetrators to another, assessing the will of the perpetrator can be an excellent alternative to resort to in situations where it is not possible to evaluate the quality of behavior based on objective rules.

Provenance: Submitted. Based on the master’s thesis by Vedran Mijanić.

Peer review: Externally peer reviewed.

Received: 22 November 2019 / Accepted: 17 September 2020 / Published online: 13 October 2020.

Funding: This research received no grant from any funding agency in public, commercial or non-profit sectors.

Authorship declaration: VM and LS planned and designed research. VM collected the judgements and literature, analyzed and interpreted the data, wrote and edited the manuscript. LS analyzed and interpreted the data and edited the manuscript. All authors approved the last version of the manuscript and accept public responsibility for all parts of the manuscript. Both authors contributed to the analysis and interpretation of the data.

Competing interests: The authors completed the ICMJE Unified Competing Interest form (available upon request from the corresponding author), and declare no conflicts of interest.

\section{ORCID}

Lucija Sokanović (D) https://orcid.org/0000-0003-4274-7789

\section{References}

Bojanić, I. (2002). Počiniteljstvo kao vlast nad djelom. Osijek: Croatian Association for Criminal Sciences and Practice.

Donatsch, A., Flachsmann, S., Hug, M. (2010). Schweizerisches Strafgesetzbuch. Zürich: Orell Füssli Velag AG.

Fabrizy, E. E., Foregger, E. (2010). Strafgesetzbuch samt ausgewählten Nebengesetzen. Wien: Manzsche Verlags- und Universitätsbuchhandlung. 
Garačić, A. (1999). Sudioništvo po novom Kaznenom zakonu i sudskoj praksi. Aktualna pitanja novog kaznenog zakonodavstva. Zagreb: Inženjerski biro. Retrieved from http://www.vsrh.hr/ CustomPages/Static/HRV/Files/AGaracic-Sudionistvo_po_novom_KZ.pdf.

Horvatić, Ž., Derenčinović, D., Cvitanović, L., (2017). Kazneno pravo opći dio II Kazneno djelo i kaznenopravne sankcije. First edition. Zagreb: Faculty of Law, University of Zagreb.

Krey, V. (2008). Deutsches Strafrecht Algemeiner Teil I. Stuttgart: Verlag W. Kohlhammer.

Kurtović Mišić, A., Krstulović Dragičević, A. (2014). Kazneno pravo temeljni pojmovi i instituti. Split: University of Split, Faculty of Law.

Lackner, K., Kühl, K. (2007). Strafgesetzbuch - Kommentar. Munich: Verlag C. H. Beck.

Novoselec, P. (2016). Opći dio kaznenog prava. Fifth (revised) edition. Osijek: Faculty of Law, University of Osijek.

Novoselec, P. (2010). Sudska praksa. Croatian Yearbook of Criminal Law and Practice, 17(2), 961-963.

Novoselec, P. (2011). Die Rezeption der Tatherrschaftslehre im kroatischen Strafrecht. In M. Heinrich (Eds.), Strafrecht als Scientia Universalis, Festschrift für Claus Roxin zum 80. Geburtstag am 15. Mai 2011 (pp. 1643-1657). Berlin/New York: Walter de Gruyter.

Novoselec, P., Bojanić, I. (2013). Opći dio kaznenog prava. Fourth (revised) edition. Zagreb: Faculty of Law, University of Zagreb.

Pavlović, Š. (2015). Kazneni zakon zakonski tekst - komentari-sudska praksa-pravna teorija. Rijeka: Libertin naklada.

Roxin, C. (2003). Strafrecht Allgemeiner Teil Band II. Munich: Verlag C. H. Beck.

Supreme Court of Croatia, No. I Kž 1109/07-5 (January 8, 2008).

Supreme Court of Croatia, No. I Kž 228/12-7 (September 1, 2015).

Supreme Court of Croatia, No. I Kž 557/2007-7 (October 21, 2008).

Supreme Court of Croatia, No. I Kž 635/91 (March 10, 1993).

Supreme Court of Croatia, No. I Kž 76/08-6 (April 9, 2008).

Supreme Court of Croatia, No. I Kž 836/09-5 (February 18, 2010).

Supreme Court of Croatia, No. I Kž 963/10-6 (October 3, 2012). 